\title{
Human Capital Reporting and Its Determinants by Polish and German Publicly Listed Companies
}

\author{
Łukasz Bryl, Szymon Truskolaski
}

\begin{abstract}
A B S T R A C T
Objective: The importance of human capital in the contemporary business environment is rising. Therefore, the aim of the study is to determine what the quality, extent and determinants of human capital disclosure in Polish and German companies are.

Research Design \& Methods: The research was conducted with the use of human capital disclosure index which was built with three main categories: employee information, internal communication and employee development policy. The sample consisted of WIG-30 and DAX entities.
\end{abstract}

Findings: The Polish firms reported worse than the German ones in terms of all studied items. The worst reporting was found in the case of participation initiatives, the best in the case of employment structure.

Implications \& Recommendations: As human capital disclosure index was insufficient in the case of both Polish and German entities, enterprises shall report more on human capital.

Contribution \& Value Added: The study compares human capital disclosure practices in the two countries with a different level of economic development.

\begin{tabular}{ll}
\hline Article type: & research paper \\
Keywords: & human capital; intellectual capital; disclosure index; publicly listed \\
& companies; stock exchange; annual report
\end{tabular}

JEL codes: G3

\section{Suggested citation:}

Bryl, Ł., \& Truskolaski, S. (2017). Human Capital Reporting and Its Determinants by Polish and German Publicly Listed Companies. Entrepreneurial Business and Economics Review, 5(2), 195-210, DOI: http://dx.doi.org/10.15678/EBER.2017.050211 


\section{INTRODUCTION}

According to the IMF methodology, Poland belongs to the group of transition economies which means that it has changed its economic model from the centrally planned economy to the market-oriented economy (since 1989). This shift had a huge impact on the way of managing local companies and the domestic financial market. Close cooperation and trade with Poland's largest (in terms of GDP) neighbour, Germany, was an important factor fostering the process of the economic transformation. In turn, Germany is a developed nation with a long history of the market-oriented economy. As the current processes of globalisation have moved many nations to the knowledge-based economy, this phenomenon is also observable in the Polish environment. One of the factors determining the pace of the knowledge-based economy development is human capital, which, surprisingly, as the most important company asset, is rarely reported in terms of value, quality and extent in corporate documents. The paper fills in this gap by identifying the inadequacy of human capital disclosure practices in company annual reports. An important challenge for human capital research is the inability of the field to identify a set of measures which are widely accepted and adopted (Massingham \& Tam, 2015).

Researchers argue that human capital is the firm's most important asset because it is the source of creativity and, therefore innovation, change, and improvement (Carson, Ranzijn, Winefiel \& Marsden, 2004). Researchers suggest that human capital reporting shall be studied due to several reasons. One of them is the proper valuation of each entity. Since traditional accounting concentrates mainly on tangible assets, there is a huge gap in valuating assets which are intangible. Human capital, in most cases, does not appear in companies' balance sheets. Moreover, its reporting is insufficient which leads to the conclusion that market does not possess full information about entities, thus the efficient market hypothesis may no longer be valid. In-depth reporting by the companies about their most important asset (human) may bring more light on their true value. According to Huang, Luther, Tayles and Haniffa (2013), research on financial analysts and fund managers suggest lack of information on company management and key corporate decision makers who could provide a firm with competitive advantage. Thus, the human capital information provided is limited, and tends to focus on directors, many of whom may be figureheads with little impact on the way companies are run and in creating value for the firm. Accordingly, analysts rely on alternative sources to get their desired information - a costly process for private shareholders. Marr (2003) identified five main reasons why firms measure and report their intellectual capital:

1. To help organisations with strategy formulation.

2. To help assess strategy execution.

3. To assist in strategic development, diversification and expansion decisions.

4. As a basis for employee compensation.

5. To communicate with external stakeholders.

The purpose of this paper is to examine the extent, quality and determinants of voluntary human capital disclosures by publicly listed companies of Poland and Germany. The research questions being asked are:

RQ1: What is the extent and quality of voluntary human capital disclosure by Polish and German companies?

RQ2: What are the determinants of human capital disclosure? 
The research method adopted for this study are: content analysis, tools of descriptive statistics and correlation analysis.

The structure of this paper is the following: Section 1 is introduction, Section 2 provides the literature review on human capital and prior research. Section 3 sets out the background of the two economies and its stock markets. Moreover, methods used in the study are described in this part. Section 4 outlines the results and discussion which is followed by Section 5 pointing to conclusions and limitations of the study, along with the future lines of research.

\section{LITERATURE REVIEW}

Human capital refers to the skills of employees, such as education, training and experience, to act in a variety of situations (Sveiby, 1997; Guthrie \& Petty, 2000). Human capital encompasses inseparable integration of a human individual, his skills, knowledge, experience, ideas rendered in the form of services in the enterprise. At the same time, the company is not the owner of human capital, however it can lease it on special terms (contract) (Brilman, 2002). The value of human capital is the total value of investments in employee training, competence and the future (Pablos, 2002). Human capital encompasses not only the knowledge and skills that individuals own and use but also their capacity to create all those resources. Human capital is made up of everything that people know, along with their capacity to learn and with others that may be beneficial for the organisation (CIC, 2012). As Ndinguri, Prieto and Machtmes, (2012) suggest, due to the specific characteristics of individuals, human capital becomes hard to be imitated, and thus plays a strategic role for the organisation to keep leadership.

In the literature, studies on human capital are often concentrated along with the studies on intellectual capital which encompasses three primary interrelated components: human capital, structural capital and relational capital ${ }^{1}$ (Sveiby, 1997). Therefore, intellectual capital and human capital terms may not be used interchangeably. According to Stewart (1997), intellectual capital is a broader term and may include: patents, processes, people's skills and experience, technologies, information about customers and suppliers. Nevertheless, many of human capital studies may be found in papers concerning intellectual capital research.

Recently, many empirical studies concentrate on the intellectual capital reporting practice around the world (e.g. Goh \& Lim, 2004, Schneider \& Samkin, 2008, Yi \& Davey, 2010; Whiting \& Woodcock, 2011, Liao, Low \& Davey, 2013; Vishnu \& Gupta, 2014; Low, Samkin \& Li, 2015). Research on intellectual capital and human capital reporting may be divided into three groups of studies concentrating on:

1. Identification and valuation.

2. Determinants of disclosure.

\footnotetext{
${ }^{1}$ An interesting and relatively simple approach concerning valuation of each of the intellectual capital components was developed by Pulic (2004). The key role in calculating each intellectual capital component is played by value added which, according to Pulic, is the sum of: operating profit, employee costs and amortisation/depreciation. Value added is later used to calculate human capital and structural capital (together with relational capital). Human capital is the sum of the total salary and wage duties for the company, structural capital (together with relational capital) is the difference between value added and human capital. As a result, intellectual capital is the sum of human capital and structural/relational capital. Despite its low level of complexity and controversies, this method has gained adequate popularity among researchers.
} 
3. International reporting comparisons.

Table 1 provides information on selected studies referring to the problem of identification and valuation of human capital.

Table 1. Selected studies on the identification and valuation of intellectual capital and human capital

\begin{tabular}{|l|l|}
\hline \multicolumn{1}{|c|}{ Authors } & \multicolumn{1}{c|}{ Key findings } \\
\hline Guthrie and Petty (2000) & $\begin{array}{l}\text { The analysis of 20 annual reports of Australian enti- } \\
\text { ties shows that there is a small number of companies } \\
\text { interested in the identification and measurement of } \\
\text { IC and HC*. Moreover, the lack of commonly accept- } \\
\text { ed research scheme seems to be an obstacle. }\end{array}$ \\
\hline $\begin{array}{l}\text { Brennan (2001), Bontis (2003), Xiao (2008), Yi and Davey } \\
\text { (2010), Singh and Kansal (2011) }\end{array}$ & Disclosure practices of IC and HC are rare. \\
\hline $\begin{array}{l}\text { Bismuth and Tojo (2008), } \\
\text { Ariff, Cahan \& Emanuel, (2014) }\end{array}$ & $\begin{array}{l}\text { The reason behind insufficient IC and HC } \\
\text { disclosure (perceived as intangible assets) are } \\
\text { conservative accounting rules. }\end{array}$ \\
\hline $\begin{array}{l}\text { Goh and Lim (2004), Schneider and Samkin (2008), Yi and Davey } \\
\text { (2010), Whiting and Woodcock (2011), Liao, Low \& Davey } \\
\text { (2013), Vishnu and Gupta (2014), Low, Samkin \& Li (2015) }\end{array}$ & $\begin{array}{l}\text { The research concentrating on practice, tech- } \\
\text { niques and methods of IC and HC reporting. }\end{array}$ \\
\hline
\end{tabular}

Source: own study on the basis of the mentioned literature or the above literature.

Although there are many theoretical attempts to measure and report human capital, the Authors state that the level of human capital disclosure by contemporary business entities is highly insufficient. The reason behind that are traditional accounting rules which are based on the conservative approach. Moreover, the plethora of human capital indicators may bring scientific confusion. The second group of studies on intellectual capital and human capital concentrating on the determinants of intellectual capital and human capital disclosure are shown in Table 2.

Selected studies on the second group of studies on human capital provide information that, although there can be many factors taken into account while analysing human capital reporting, the most important ones appear to be the firm size and the industry. The third group of studies on human capital disclosure is presented in Table 3 .

The theoretical framework as well as empirical evidence provide information that intellectual capital and human capital disclosure is still a relatively rare phenomenon, despite its great importance and effect on the strategic performance of companies. Research suggests that the reason behind that is the lack of one commonly recognised definition of human capital, as well as the ways of its identification and measuring. Moreover, reporting standards on human capital differ significantly between countries and as most of studies suggest the quality and extent of disclosure depends on the level of the economic development of the firm's country of origin. 
Table 2. Determinants of intellectual capital and human capital

\begin{tabular}{|l|l|}
\hline \multicolumn{1}{|c|}{ Authors } & \multicolumn{1}{c|}{ Key findings } \\
\hline $\begin{array}{l}\text { Guthrie and Petty (2000), April, Bosma } \\
\text { \& Deglon (2003), Goh and Lim (2004), } \\
\text { Yi and Davey, (2010), Curado et al. } \\
\text { (2011), Liao, Low \& Davey (2013), An, } \\
\text { Harun \& Sharma (2014) }\end{array}$ & $\begin{array}{l}\text { The authors stress the crucial importance of the criteria being } \\
\text { taken in the study. Moreover, the criteria choice is often } \\
\text { determined by the study objective. }\end{array}$ \\
\hline Bozzolan, Favotto \& Ricceri (2003) & $\begin{array}{l}\text { The study on the sample of 30 Italian, non-financial publicly } \\
\text { listed companies suggests that the industry and the firm size } \\
\text { are significantly important factors in IC and HC* disclosure. }\end{array}$ \\
\hline Pablos (2003) & $\begin{array}{l}\text { Industry plays an important role in human capital disclosure in } \\
\text { Danish, Swedish and Spanish entities - the banking sector was } \\
\text { ahead of other sectors in human capital reporting. }\end{array}$ \\
\hline Guthrie, Petty \& Ricceri (2006) & $\begin{array}{l}\text { The research on 50 listed entities in Australia and 100 entities } \\
\text { in Hong Kong. There is a positive correlation between volun- } \\
\text { tary intellectual capital and human capital disclosures and the } \\
\text { company size. }\end{array}$ \\
\hline Bruggen, Vergauwen \& Dao (2009) & $\begin{array}{l}\text { Industry and firm size are a key factor in IC and HC disclosure } \\
\text { (a sample of Australian companies). }\end{array}$ \\
\hline
\end{tabular}

Abbreviations stand for intellectual capital (IC) and human capital (HC) respectively

Source: own study.

Table 3. International comparative analysis of intellectual capital and human capital reporting

\begin{tabular}{|l|l|}
\hline \multicolumn{1}{|c|}{ Authors } & \multicolumn{1}{c|}{ Key findings } \\
\hline Pablos (2003) & $\begin{array}{l}\text { The study on Danish, Swedish and Spanish companies showed that Swe- } \\
\text { dish entities reported best on human capital, whereas Spanish firms worst. }\end{array}$ \\
\hline Abeysekera (2008) & $\begin{array}{l}\text { The quality of IC and HC* reporting is higher in the case of Singapore com- } \\
\text { panies than firms from Sri Lanka. }\end{array}$ \\
\hline Yi and Davey (2010) & IC and HC disclosure depends on the firm's country of origin. \\
\hline Joshi, Ubha \& Sidhu (2012) & $\begin{array}{l}\text { A sample of Indian and Australian IT companies suggests that there is a gap } \\
\text { between IC and HC disclosure between enterprises from developed and } \\
\text { developing nations. }\end{array}$ \\
\hline $\begin{array}{l}\text { Wang, Sharma and Davey } \\
\text { (2016) }\end{array}$ & $\begin{array}{l}\text { Publicly listed IT entities from India perform better in IC and HC disclosure } \\
\text { than Chinese ones. }\end{array}$ \\
\hline
\end{tabular}

Abbreviations stand for intellectual capital (IC) and human capital (HC) respectively

Source: own study on the basis of the mentioned literature or the above literature.

Previous empirical findings argue for more research on human capital reporting and its determinants, especially in relation to emerging countries. As this paper is focused on studying the extent of human capital disclosure and its determinants among enterprises from the countries on a different level of development, two research hypotheses were formed.

H1: Enterprises from developed nations report better on human capital than firms from transition economies.

H2: The size of the company (measured by market value, revenue and employment) and the industry determine the quality and extent of human capital reporting. 


\section{MATERIAL AND METHODS}

The research compares the annual reports and other publicly available corporate documents ${ }^{2}$ for the financial year 2015 of top 30 Polish companies to those of German companies. The research method adopted for this study consists in: content analysis, tools of descriptive statistics and correlation analysis. Guthrie and Petty (2000) consider annual report of the company as generally most widely distributed of all public documents; what is more, the management of the firm can control the reporting of information in this document.

\section{The Studied Sample Description}

Poland and Germany are two closely linked economies on a different level of development. In Poland there is one stock exchange (Warsaw Stock Exchange - WSE), and in Germany there are nine stock exchanges, however, the most important one is Deutsche Börse based in Frankfurt. Data concerning both financial markets are shown below.

Table 4. The comparison of Polish and German stock exchanges in 2015

\begin{tabular}{|l|c|c|}
\cline { 2 - 3 } \multicolumn{1}{c|}{} & Warsaw Stock Exchange & Deutsche Börse \\
\hline Annual turnover (EUR mln) & 49055 & 1409830 \\
\hline Market capitalisation (EUR mln) & 126017 & 1570301 \\
\hline Listed companies & 905 & 619 \\
\hline No. of employees & 369 & 5283 \\
\hline Year of establishment & 1991 & 1585 \\
\hline
\end{tabular}

Source: own study based on the Federation of European Securities Exchanges (2016).

Deutsche Börse, as the more established stock exchange (since 1585), is much larger than the WSE, taking into account almost all major criteria. The yearly turnover of the shares traded is $29 \mathrm{x}$ larger, the value of all listed companies is $12 \mathrm{x}$ larger, whereas the total number of employee is 14 times higher in the case of Deutsche Börse than in the WSE. Only in terms of the number of listed companies the WSE records a greater value (905 vs. 619).

The level of the development of financial markets indicates the level of a nation's economy, including the largest enterprises. In the case of Poland and Germany, the largest companies are listed on stock exchanges and often build up the main market indices. This paper examines 30 publicly listed enterprises in each country.

For the purpose of the study, Polish and German companies belonging to WIG-30 3 and $D A X^{4}$ respectively were researched (October 2016). Such a choice of studied companies derives from the fact that, according to the literature review, intellectual capital and human capital disclosure is more frequent in publicly listed firms. Entities were

\footnotetext{
${ }^{2}$ In addition to the annual report, the following documents were analysed (if available): the CSR report, the management report and the financial statement. However, in some cases the annual report was a comprehensive document covering all the data needed. Such a situation occurred mainly in the case of German companies.

${ }^{3}$ WIG-30 includes the following entities: Alior, Asseco, Bogdanka, BZWBK, CCC, CD Projekt, Cyfrowy Polsat, Enea, Energa, Eurocash, Grupa Azoty, GTC, ING, JSW, Kernel, KGHM, Lotos, LPP, Mbank, Millenium, Orange, Pekao, PGE, PGNIG, PKN Orlen, PKO BP, PKP Cargo, PZU, Synthos, Tauron.

${ }^{4}$ DAX includes the following entities: Adidas, Allianz, BASF, Bayer, Beiersdorf, BMW, Commerzbank, Continental, Daimler, Deutsche Bank, Deutsche Borse, DHL, Deutsche Telekom, EON, Fresenius Medical Care, Fresenius, Heidelberg, Henkel, Infineon, Linde, Lufthansa, Merck, Muenchener Rueck, ProSieben, RWE, SAP, Siemens, ThyssenKrupp, Volkswagen, Vonovia.
} 
compared in terms of the market value, total revenue and employment. To measure the market value the quantity of shares and unit stock price on 4th November 2016 were taken, however, the total revenue refers to the values for the yearly 2015 turnover, whereas the employment category was adopted as the average number of employees during 2015. In the case of the Polish companies, 8 entities were classified to Banks and Insurance, 7 to Production, 8 to Energy and 7 to Services. However, in the case of the German enterprises, most of the studied firms belonged to the Production entities (15), 8 to Services, 5 to Banks and Insurance and 2 to Energy. Figures describing the research sample are presented in the table below.

Table 5. The comparison of the studied Polish and German enterprises

\begin{tabular}{|c|c|c|c|c|}
\cline { 2 - 5 } \multicolumn{1}{c|}{} & \multicolumn{2}{c|}{ WIG-30 $(\mathbf{n = 3 0})$} & \multicolumn{2}{c|}{ DAX $(\mathbf{n = 3 0})$} \\
\cline { 2 - 5 } & Total & Mean & Total & Mean \\
\hline Market value (bln EUR) & 83.2 & 2.8 & 1350 & 45 \\
\hline Revenue (bln EUR) & 4.7 & 1.5 & 1209 & 40.3 \\
\hline Employment & 398375 & 13279 & 3664087 & 122136 \\
\hline
\end{tabular}

Source: own study on the basis of the studied sample.

\section{Content Analysis}

For the purpose of the study content analysis was adopted as a research method. Content analysis is defined as a technique for gathering data (Abeysekera, 2007). The aim is to codify qualitative and quantitative data into pre-defined categories in order to receive quantitative scales of different levels of complexity (Guthrie, Petty \& Ricceri 2004; Guthrie \& Petty, 2000; Abeysekera, 2007; Dumay \& Cai, 2015). It should be mentioned that content analysis has some limitations. One of them is the problem of subjectivity in assessing each category (coding process). Another major problem is the interdependence on companies to report certain items. Moreover, there also has to be the assumption made that information provided by the companies are reliable. However, despite these arguments, according to Schneider and Samkin (2008), Guthrie and Petty (2000), Yi and Davey (2010) content analysis is perceived to be empirically valid in social sciences, intellectual capital disclosure and in the reporting fields of accounting research.

\section{The Structure of Human Capital Disclosure Index}

To assess the extent and quality of human capital reporting a disclosure index was applied. An important part in constructing it is the decision on scale scheme. The selection of scale scheme used to score IC items differs in specific studies. Schneider and Samkin (2008), and Yi and Davey (2010) adopted a six-point scale (from 0 to 5); Whiting and Miller (2008) established the quality criteria on a three-point scale (from 0 to 2, 0 for nondisclosure, 1 for qualitative disclosure and 2 for quantitative disclosure); Brennan (2001) and Abeysekera and Guthrie (2005) used a two-point scale (0-1, 0 represents nondisclosure and 1 represents disclosure). In this study a five-point scale was adopted - the details are presented below:

1. No disclosure (0 pts.): there was no information in corporate documents.

2. Narrative (1 pts.): information presented in a basic (short) narrative form.

3. Numerical (2 pts.): information presented in a numerical form. 
4. Monetary (3 pts.): information presented in a monetary form (alternatively more in-depth numerical forms appear).

5. Qualitative and quantitative (4 pts.): combination of qualitative and quantitative information.

Secondly, a list of the items of human capital was identified based on: prior literature, the researchers' own knowledge of the studied firms and the initial study on the sample of 2 enterprises from Poland and Germany. An analysis of human capital disclosure is often based on individual assumptions taken by the researchers. One of the reasons is the plethora of scientific approaches developed on the theoretical level. Massingham and Tam (2015) include three items in human capital, namely: employee capability (measured by: qualifications, experience, skills and knowledge), employee satisfaction (measured by: affective attachment locus of control, calculative reward, calculative approval and personal outcome expectancy) and employee commitment (measured by: trust and careerism). Liao et al. (2013) include two items in human capital, which are employee satisfaction (understood as: employee support, employee safety, employee retention, work-family balance, employee motivation and employee satisfaction) and employee capital (understood as: intelligence, know-how, education/training, competence, expertise, brain power, specialist, human resource). Yi and Davey (2010) identify four items, these are: employee (measured by: indicators related to employees), education/training (measured by: education or training programmes provided by the company), work-related knowledge (measured by: knowledge acquired for the job or training by employees), entrepreneurial spirit (measured by: innovation and risk-taking).

Literature review on human capital items and national context of the studied firms enabled us to form a comprehensive and broad spectrum of all (to our best knowledge) items concerning human capital disclosure possible to identify and measure in the corporate, officially released documents. This group of items was later applied and tested in terms of prevalence in the initial study on a small sample of Polish and German entities ${ }^{5}$. Taking into account that the national context of the studied firms in the research process is a common approach in the research on human capital, as suggested by Liao, Low and Davey (2013) and Wang, Sharma and Davey (2016).

As a result, we decided, basing on the country-specific features and the initial study, to identify three main human capital categories with a further division. Details on human capital disclosure index are presented in Table 6.

These items partially agree with prior research, however the structure of the index shall be perceived as unique. Two human capital items (internal communication policy and development programme) were difficult to measure with the use of disclosure index due to the fact that companies tend to report on those categories mainly in a narrative form, thus in these cases Likert's scale (0-4) was adopted. Three human capital items (Voluntary Leave Plan, Trade Unions and Stock Option Plan) were of specific case. In some of the studied entities the information was given that there is no Voluntary Leave Plan, Trade Unions or Stock Option Plan. Therefore, the adoption of disclosure index would be pointless. Thus, we decided to give the maximum score of four when such a situation appeared. A similar approach was undertaken by Yi and Davey (2010).

\footnotetext{
${ }^{5}$ As it will be later presented in the Results and Discussion section, some items were reported very rarely which was the consequence of the broad spectrum of human capital items considered.
} 
Table 6. The description of human capital disclosure index

\begin{tabular}{|c|c|}
\hline \multicolumn{1}{|c|}{ Human capital category } & Methods \\
\hline 1. Employee information & Mean 1.1-1.3 \\
\hline 1.1. Employee benefits & disclosure index \\
\hline 1.2. Employment structure & disclosure index \\
\hline 1.3. Voluntary Leave Transfer Programme & disclosure index \\
\hline 2. Internal communication & Mean 2.1-2.4 \\
\hline 2.1. Internal communication policy & Likert's scale \\
\hline 2.2. Trade unions & disclosure index \\
\hline 2.3. Employee satisfaction survey & disclosure index \\
\hline 2.4. Participation initiatives & disclosure index \\
\hline 3. Employee development policy & Mean 3.1-3.4 \\
\hline 3.1. Development programme & Likert's scale \\
\hline 3.2. Incentive scheme & disclosure index \\
\hline 3.3. Stock Option Plan & disclosure index \\
\hline 3.4. Employee voluntary service & disclosure index \\
\hline Human capital overall score & Mean 1-3 \\
\hline
\end{tabular}

Source: own study.

In the study we perceive the above-mentioned items as equally important, thus there were no weighs put to any of the item. The final score of human capital disclosure is the mean value of employee info, internal communication and employee development policy. The coding process did not provide any obstacles, mainly due to an easy public access to corporate documents.

\section{RESULTS AND DISCUSSION}

The study conducted on the sample of total 60 entities provides useful data on human capital disclosure. Mean human capital values were higher in the case of the German (2.15) entities than the Polish ones (1.75). Table 7 presents human capital disclosure values and the category breakdown.

The Polish entities reported worse than the German ones in terms of all the studied categories. The largest differences were reported in terms of employee satisfaction survey and development plan. Meanwhile, the smallest differences were found in the case of Voluntary Leave Plan, Trade Unions and Stock Option Plan. Both Polish and German companies performed worst in reporting about participation initiatives (0.12 and 0.5, respectively) and Voluntary Leave Plan (1.1 and 1.3, respectively). However, the studied enterprises reported well on employee benefits (2.57 and 3.15, respectively) and Stock Option Plan (3.07 and 3.27, respectively). To sum up the quality of human capital disclosure, it shall be stressed that, although in some categories both the Polish and German firms perform well, on average the human capital disclosure is not sufficient. Mean human capital disclosure index values were 1.75 (43\%) for the Polish companies and 2.15 (53.8\%) for the German ones. The achieved results confirm prior research of Abeysekera (2008), Yi \& Davey (2010) concerning the national context of the studied firms and analyses of Joshi et al. (2012) who argue that more developed countries report better in terms of the quality of human capital disclosure than developing nations. However, the results are not in line with the studies of Wang, Sharma 
and Davey (2016) on Indian and Chinese entities. However, although there is a difference in the level of the economic development between India and China (measured by GDP per capita), still both countries are classified as developing nations.

Table 7. The average human capital disclosure values with the breakdown of categories

\begin{tabular}{|c|c|c|}
\hline Human capital category & Mean PL & Mean GER \\
\hline 1. Employee information & $\mathbf{1 . 8 5}$ & $\mathbf{2 . 2 9}$ \\
\hline 1.1. Employee benefits & 2.57 & 3.15 \\
\hline 1.2. Employment structure & 1.74 & 2.4 \\
\hline 1.3. Voluntary Leave Transfer Programme & 1.1 & 1.3 \\
\hline 2. Internal communication & $\mathbf{1 . 2 3}$ & $\mathbf{1 . 4 6}$ \\
\hline 2.1. Internal communication policy & 1.32 & 1.6 \\
\hline 2.2. Trade unions & 1.37 & 1.53 \\
\hline 2.3. Employee satisfaction survey & 1.1 & 2.2 \\
\hline 2.4. Participation initiatives & 0.12 & 0.5 \\
\hline 3. Employee development policy & $\mathbf{2 . 1 7}$ & $\mathbf{2 . 7}$ \\
\hline 3.1. Development programme & 1.87 & 2.86 \\
\hline 3.2. Incentive scheme & 2.02 & 2.73 \\
\hline 3.3. Stock Option Plan & 3.07 & 3.27 \\
\hline 3.4. Employee voluntary service & 1.66 & 1.93 \\
\hline Human capital overall score & $\mathbf{1 . 7 5 ( 4 3 \% )}$ & $\mathbf{2 . 1 5}$ (53.8\%) \\
\hline
\end{tabular}

Source: own study.

In the second step of the study, the extent of human capital disclosure was analysed. The extent of human capital disclosure may be measured by its frequency which is equal to the quantity of firms disclosing each human capital item. The results are presented in Table 8.

Table 8. The frequency (in \%) of reporting on the studied items of human capital

\begin{tabular}{|c|c|c|}
\hline Human capital category & PL & GER \\
\hline 1. Employee information & - & - \\
\hline 1.1. Employee benefits & 29 & 30 \\
\hline 1.2. Employment structure & 30 & 30 \\
\hline 1.3. Voluntary Leave Transfer Programme & 13 & 17 \\
\hline 2. Internal communication & - & - \\
\hline 2.1. Internal communication policy & 24 & 27 \\
\hline 2.2. Trade unions & 14 & 23 \\
\hline 2.3. Employee satisfaction survey & 15 & 22 \\
\hline 2.4. Participation initiatives & 2 & 10 \\
\hline 3. Employee development policy & - & - \\
\hline 3.1. Development programme & 28 & 30 \\
\hline 3.2. Incentive scheme & 25 & 30 \\
\hline 3.3. Stock Option Plan & 28 & 28 \\
\hline 3.4. Employee voluntary service & 15 & 21 \\
\hline
\end{tabular}

Source: own study.

From Table 8 it can be concluded that only one human capital item was disclosed by all the Polish and German companies (information on employment structure). However three human capital items were reported by almost all studied firms (employee benefits, development programme and Stock Option Plan). The least frequently disclosed human 
capital item were participation initiatives, which was also observable in terms of human capital disclosure quality. Apparently, more often than participation initiatives, but still more rarely than other human capital items trade unions and employee satisfaction were disclosed. What is interesting in terms of the extent of human capital disclosure are the best scoring fields in the case of the Polish and German firms reported similarly, however major differences appeared in the worst scoring of human capital items. The findings are partly contradictory with the results of Wang, Sharma and Davey (2016).

Human capital disclosure varied among the studied industries. Four industries were distinguished (Banks and Insurance, Energy and Mining, Production and Services). The results are presented in Table 9.

Table 9. Human capital disclosure against the industry

\begin{tabular}{|l|c|c|c|c|c|c|c|c|c|c|}
\hline \multirow{2}{*}{ Industry* } & \multicolumn{4}{|c|}{ Germany } & \multicolumn{5}{c|}{ Poland } \\
\cline { 2 - 10 } & Total & $\mathbf{B}$ & E\&M & $\mathbf{P}$ & $\mathbf{U}$ & Total & $\mathbf{B}$ & E\&M & $\mathbf{P}$ & $\mathbf{U}$ \\
\hline \multicolumn{1}{|c}{ Number } & $\mathbf{3 0}$ & $\mathbf{5}$ & $\mathbf{2}$ & $\mathbf{1 5}$ & $\mathbf{8}$ & $\mathbf{3 0}$ & $\mathbf{8}$ & $\mathbf{8}$ & $\mathbf{7}$ & $\mathbf{7}$ \\
\hline Human capital overall score & $\mathbf{2 . 1 5}$ & $\mathbf{1 . 9 2}$ & $\mathbf{1 . 9 1}$ & $\mathbf{2 . 2 3}$ & $\mathbf{2 . 2 0}$ & $\mathbf{1 . 7 5}$ & $\mathbf{2 . 0 6}$ & $\mathbf{2 . 4 9}$ & $\mathbf{1 . 1 9}$ & $\mathbf{1 . 1 1}$ \\
\hline 1. Employee info & $\mathbf{2 . 2 9}$ & $\mathbf{2 . 5 8}$ & $\mathbf{1 . 8 6}$ & $\mathbf{2 . 3 3}$ & $\mathbf{2 . 1 6}$ & $\mathbf{1 . 8 5}$ & $\mathbf{1 . 7 4}$ & $\mathbf{2 . 8 2}$ & $\mathbf{1 . 2 7}$ & $\mathbf{1 . 4 5}$ \\
\hline 1.1.Employee benefits & 3.15 & 3.20 & 3.25 & 3.03 & 3.31 & 2.57 & 2.63 & 3.31 & 2.14 & 2.07 \\
\hline 1.2. Employment structure & 2.40 & 2.33 & 2.33 & 2.56 & 2.17 & 1.74 & 1.33 & 2.60 & 1.52 & 1.43 \\
\hline 1.3. Voluntary Leave Transfer Programme & 1.33 & 2.20 & 0.00 & 1.40 & 1.00 & 1.11 & 1.00 & 2.43 & 0.14 & 0.86 \\
\hline 2. Internal communication & $\mathbf{1 . 4 6}$ & $\mathbf{0 . 8 8}$ & $\mathbf{1 . 2 5}$ & $\mathbf{1 . 5 8}$ & $\mathbf{1 . 6 6}$ & $\mathbf{1 . 2 3}$ & $\mathbf{1 . 9 3}$ & $\mathbf{1 . 9 2}$ & $\mathbf{0 . 3 2}$ & $\mathbf{0 . 5 4}$ \\
\hline 2.1. Internal communication policy & 1.60 & 0.90 & 1.00 & 1.83 & 1.75 & 1.32 & 2.03 & 1.65 & 0.68 & 0.76 \\
\hline 2.2. Trade unions & 1.53 & 1.00 & 2.00 & 1.53 & 1.75 & 1.37 & 1.43 & 3.13 & 0.17 & 0.17 \\
\hline 2.3. Employee satisfaction survey & 2.20 & 1.40 & 2.00 & 2.33 & 2.50 & 1.11 & 2.38 & 1.14 & 0.14 & 0.50 \\
\hline 2.4. Participation initiatives & 0.50 & 0.20 & 0.00 & 0.60 & 0.63 & 0.12 & 0.17 & 0.00 & 0.00 & 0.33 \\
\hline 3. Employee development policy & $\mathbf{2 . 7 0}$ & $\mathbf{2 . 3 1}$ & $\mathbf{2 . 6 3}$ & $\mathbf{2 . 7 9}$ & $\mathbf{2 . 7 9}$ & $\mathbf{2 . 1 7}$ & $\mathbf{2 . 5 1}$ & $\mathbf{2 . 7 3}$ & $\mathbf{1 . 9 7}$ & $\mathbf{1 . 3 3}$ \\
\hline 3.1. Development programme & 2.86 & 2.53 & 2.50 & 3.09 & 2.71 & 1.87 & 2.21 & 2.44 & 1.52 & 1.19 \\
\hline 3.2. Incentive scheme & 2.73 & 2.70 & 2.50 & 2.73 & 2.81 & 2.02 & 3.06 & 2.06 & 1.64 & 1.14 \\
\hline 3.3. Stock Option Plan & 3.27 & 3.40 & 3.00 & 3.07 & 3.63 & 3.07 & 3.00 & 3.50 & 3.43 & 2.29 \\
\hline 3.4. Employee voluntary service & 1.93 & 0.60 & 2.50 & 2.27 & 2.00 & 1.66 & 1.75 & 2.86 & 1.29 & 0.71 \\
\hline
\end{tabular}

* The following industries were identified: B - Banks \& Insurance, E\&M - Energy \& Mining, P - Production, U -Services Source: own study.

Human capital disclosure values differed among industries. The German companies performed best in Production and Services industry (mean values of human capital disclosure: 2.23 and 2.2, respectively), whereas the Polish entities scored the best performance in Energy and Mining industry (2.49). What is interesting, German Energy and Mining industry reported worst of all German companies (1.91). The worst disclosing Polish industry appeared to be Services (1.11). These findings are not in line with the conclusions of Pablo (2003) who argued that the banking sector reports best (a sample of Danish, Swedish and Spanish enterprises). On the contrary, in German banking entities human capital disclosure index was the second worst with the score almost similar (1.92 vs. 1.91) to the Energy and Mining industry. In Poland in the banking sector the quality of human capital disclosure was average.

Literature studies suggest the importance of other factors determining human capital disclosure, such as the firm size. In our study the firm size was defined as 
Market Value and Number of Employees. Table 10 presents human capital disclosure values depending on the market value.

Table 10. Human capital disclosure and the market value

\begin{tabular}{|c|c|c|c|c|c|c|c|c|c|c|}
\hline \multirow{3}{*}{ Market Value } & \multicolumn{5}{|c|}{ Germany } & \multicolumn{5}{|c|}{ Poland } \\
\hline & \multirow{2}{*}{ Total } & 1st & 2nd & 3rd & 4th & \multirow{2}{*}{ Total } & 1st & 2nd & 3rd & 4th \\
\hline & & \multicolumn{4}{|c|}{ quartiles } & & \multicolumn{4}{|c|}{ quartiles } \\
\hline Number & 30 & 1 & 8 & 8 & 13 & 30 & 14 & 7 & 7 & 2 \\
\hline Human capital overall score & 2.15 & 2.52 & 1.89 & 2.06 & 2.34 & 1.75 & 1.45 & 1.79 & 2.12 & 2.43 \\
\hline 1. Employee info & 2.29 & 1.44 & 2.16 & 2.18 & 2.51 & 1.85 & 1.70 & 1.73 & 2.00 & 2.78 \\
\hline 1.1.Employee benefits & 3.15 & 3.00 & 3.19 & 3.25 & 3.08 & 2.57 & 2.39 & 2.79 & 2.43 & 3.50 \\
\hline 1.2. Employment structure & 2.40 & 1.33 & 2.29 & 2.42 & 2.54 & 1.74 & 1.71 & 1.36 & 1.86 & 2.83 \\
\hline 1.3. Voluntary Leave Transfer Programme & 1.33 & 0.00 & 1.00 & 0.88 & 1.92 & 1.11 & 1.00 & 0.67 & 1.50 & 2.00 \\
\hline 2. Internal communication & 1.46 & 2.63 & 1.02 & 1.44 & 1.65 & 1.23 & 0.76 & 1.36 & 1.88 & 1.75 \\
\hline 2.1. Internal communication policy & 1.60 & 2.50 & 1.19 & 1.38 & 1.92 & 1.32 & 0.99 & 1.23 & 2.08 & 1.25 \\
\hline 2.2. Trade unions & 1.53 & 4.00 & 1.25 & 2.00 & 1.23 & 1.37 & 0.85 & 1.86 & 1.67 & 3.00 \\
\hline 2.3. Employee satisfaction survey & 2.20 & 3.00 & 1.38 & 1.75 & 2.92 & 1.11 & 0.54 & 0.67 & 2.14 & 2.50 \\
\hline 2.4. Participation initiatives & 0.50 & 1.00 & 0.25 & 0.63 & 0.54 & 0.12 & 0.00 & 0.50 & 0.00 & 0.00 \\
\hline 3. Employee development policy & 2.70 & 3.50 & 2.49 & 2.56 & 2.85 & 2.17 & 1.88 & 2.27 & 2.49 & 2.75 \\
\hline 3.1. Development programme & 2.86 & 3.00 & 2.42 & 3.17 & 2.92 & 1.87 & 1.43 & 1.64 & 2.67 & 3.00 \\
\hline 3.2. Incentive scheme & 2.73 & 4.00 & 2.56 & 2.69 & 2.77 & 2.02 & 1.64 & 2.07 & 2.57 & 2.50 \\
\hline 3.3. Stock Option Plan & 3.27 & 4.00 & 3.25 & 2.88 & 3.46 & 3.07 & 3.43 & 2.86 & 2.86 & 2.00 \\
\hline 3.4. Employee voluntary service & 1.93 & 3.00 & 1.75 & 1.50 & 2.23 & 1.66 & 1.00 & 2.33 & 1.86 & 3.50 \\
\hline
\end{tabular}

Source: own study.

Market values of the studied companies from both countries are significantly different due to the level of financial markets development, which was shown in Section 3. Thus, the research was conducted with the percentile division according to each country. The smallest German firms (from the first quartile) had to be excluded due to the fact that there was only one enterprise. Nevertheless, the highest human capital disclosure was reported by the entities with the greatest market value. Such a phenomenon was observed in relation to both German and Polish companies.

The second factor influencing human capital disclosure taken into account in our study was the number of employees. The results are presented in Table 11.

The data in Table 11 suggest that the greatest human capital disclosure values can be observed in the case of the largest German and Polish enterprises. The largest Polish entities performed on average the same as the German ones (2.34 vs. 2.35). In the German firms a linear trend of human capital disclosure values was observed (the larger enterprise the better human capital reporting). Such a phenomenon was not recorded for the Polish companies which tend to form two distinct groups - the largest companies (in the 4th quartile) performed much better than the rest (in quartiles 1-3).

To find the human capital disclosure determinants we conducted a correlation analysis with the industry and country breakdown ${ }^{6}$.

\footnotetext{
${ }^{6}$ As not all variables are normally distributed (e.g. Market Value and Revenue in Poland) as shown by ShapiroWilk test, we used Spearman correlation coefficient. The significance levels in Table 12 (marked with asterisks) show the results of the $t$ test results on variable independence.
} 
Moreover, in a firm size we included market value, revenue and employment. Table 12 shows the results.

Table 11. Human capital disclosure and employment

\begin{tabular}{|c|c|c|c|c|c|c|c|c|c|c|}
\hline \multirow{3}{*}{ Employment } & \multicolumn{5}{|c|}{ Germany } & \multicolumn{5}{|c|}{ Poland } \\
\hline & \multirow{2}{*}{ Total } & 1st & 2nd & 3rd & 4th & \multirow{2}{*}{ Total } & 1st & 2nd & 3rd & 4th \\
\hline & & \multicolumn{4}{|c|}{ quartiles } & & \multicolumn{4}{|c|}{ quartiles } \\
\hline Number & 30 & 8 & 7 & 7 & 8 & 30 & 8 & 7 & 7 & 8 \\
\hline Human capital overall score & 2.15 & 1.86 & 2.03 & 2.37 & 2.35 & 1.75 & 1.19 & 1.84 & 1.62 & 2.34 \\
\hline 1. Employee info & 2.29 & 2.12 & 2.17 & 2.47 & 2.42 & 1.85 & 1.44 & 1.71 & 1.48 & 2.70 \\
\hline 1.1.Employee benefits & 3.15 & 3.19 & 3.29 & 2.93 & 3.19 & 2.57 & 1.88 & 2.71 & 2.29 & 3.38 \\
\hline 1.2. Employment structure & 2.40 & 2.42 & 2.24 & 2.62 & 2.33 & 1.74 & 1.71 & 1.43 & 1.86 & 1.94 \\
\hline 1.3. Voluntary Leave Transfer Programme & 1.33 & 0.75 & 1.00 & 1.86 & 1.75 & 1.11 & 0.75 & 0.67 & 0.29 & 2.71 \\
\hline 2. Internal communication & 1.46 & 0.97 & 1.36 & 1.77 & 1.77 & 1.23 & 0.60 & 1.43 & 0.97 & 1.90 \\
\hline 2.1. Internal communication policy & 1.60 & 1.25 & 1.57 & 1.64 & 1.94 & 1.32 & 0.69 & 1.71 & 1.20 & 1.71 \\
\hline 2.2. Trade unions & 1.53 & 1.25 & 1.43 & 2.14 & 1.38 & $\mid 1.37$ & 0.88 & 1.33 & 0.50 & 2.71 \\
\hline 2.3. Employee satisfaction survey & 2.20 & 1.25 & 1.71 & 3.00 & 2.88 & 1.11 & 0.29 & 1.29 & 1.00 & 1.86 \\
\hline 2.4. Participation initiatives & 0.50 & 0.13 & 0.71 & 0.29 & 0.88 & 0.12 & 0.00 & 0.17 & 0.33 & 0.00 \\
\hline 3. Employee development policy & 2.70 & 2.49 & 2.57 & 2.88 & 2.85 & 2.17 & 1.52 & 2.38 & 2.40 & 2.43 \\
\hline 3.1. Development programme & 2.86 & 2.83 & 2.71 & 2.95 & 2.92 & $\mid 1.87$ & 1.25 & 1.67 & 2.38 & 2.23 \\
\hline 3.2. Incentive scheme & 2.73 & 2.63 & 2.71 & 3.00 & 2.63 & 2.02 & 0.81 & 2.71 & 2.50 & 2.19 \\
\hline 3.3. Stock Option Plan & 3.27 & 3.00 & 3.14 & 3.71 & 3.25 & 3.07 & 2.50 & 3.57 & 3.29 & 3.00 \\
\hline 3.4. Employee voluntary service & 1.93 & 1.50 & 1.71 & 1.86 & 2.63 & 1.66 & 1.50 & 1.57 & 1.43 & 2.14 \\
\hline
\end{tabular}

Table 12. Correlation analysis between human capital disclosure index and market value, revenue and employment with country/industry breakdown

\begin{tabular}{|c|c|c|c|c|c|}
\cline { 2 - 4 } \multicolumn{1}{c|}{$\begin{array}{c}\text { Human capital } \\
\text { index }\end{array}$} & Market Value & Revenue & Employment & Country & Industry \\
\cline { 2 - 4 } & -0.1147 & $0.3523^{*}$ & $0.3849^{* *}$ & Germany & \multirow{2}{*}{ All sectors } \\
\hline \multirow{4}{*}{$\begin{array}{c}\text { Human capital } \\
\text { index }\end{array}$} & $0.3496^{*}$ & 0.2781 & $0.5707^{* * *}$ & Poland & \\
\cline { 2 - 4 } & -0.2551 & 0.3688 & 0.2884 & & Banking \\
\cline { 2 - 4 } & 0.2579 & $0.5896^{* * *}$ & $0.5683^{* * *}$ & \multirow{3}{*}{ Both countries } & Energy \& Mining \\
\cline { 2 - 4 } & 0.5094 & $0.4851^{*}$ & 0.4256 & & Production \\
\hline \multirow{4}{*}{$\begin{array}{c}\text { Human capital } \\
\text { index }\end{array}$} & 0.4798 & $0.8786^{* *}$ & 0.8 & & Services \\
\cline { 2 - 4 } & - & - & - & \multirow{4}{*}{ Germany } & Energy \& Mining \\
\cline { 2 - 4 } & 0.0099 & $0.5336^{* *}$ & $0.5339^{* *}$ & & Production \\
\cline { 2 - 4 } \cline { 2 - 3 } & 0.2403 & 0.2138 & 0.1318 & & Services \\
\hline \multirow{4}{*}{$\begin{array}{c}\text { Human capital } \\
\text { index }\end{array}$} & 0.0919 & 0.2856 & 0.3777 & & Banking \\
\cline { 2 - 4 } & 0.6071 & 0.5893 & $0.7106^{*}$ & \multirow{2}{*}{ Poland } & Energy \& Mining \\
\cline { 2 - 4 } & 0.666 & $0.8258^{* *}$ & 0.6398 & & Production \\
\cline { 2 - 4 } & -0.1343 & $0.7567^{* *}$ & 0.5992 & & Services \\
\hline
\end{tabular}

Source: own study.

The strongest relations were recorded between human capital disclosure values and employment and revenue in both countries in the Production industry. Also the relation between human capital disclosure index and revenue in the Banking industry in Germany and in the Services in Poland appeared to be significantly important. The results partially confirm previous studies of Guthrie, Petty and Ricceri (2006) and 
Bruggen, Vergauwen and Dao (2009) concerning a positive relation between the quality of voluntary human capital disclosure and company size.

\section{CONCLUSIONS}

The study conducted in this paper examined the extent, quality and determinants of voluntary human capital disclosures by Polish and German publicly listed companies. The mean value of human capital disclosure is insufficient, which corresponds with the research of Guthrie and Petty (2000), Brennan (2001), Bontis (2003), Xiao (2008), Yi and Davey (2010) and Singh and Kansal (2011). Even the best scoring entities could not reach the level of $80 \%$ of maximum human capital disclosure index. In Poland the greatest human capital disclosure values were found in the case of PGE (3.13-78.2\%), in turn in Germany - Bayer (3.0877.1\%). Moreover, the Polish enterprises performed worse than the German ones, which is in line with the similar studies of Abeysekera (2008), Yi and Davey (2010) and Joshi, Ubha \& Sidhu (2012), in the sense that entities from developed nations report on human capital more comprehensively than firms from a developing country. However, studies of Wang et al. (2016) suggest the opposite relation. Among the factors influencing human capital disclosure the firm size (understood as revenue and employment) and industry were determined as significantly important, although the relations were different in each country and dependable upon the industry. Such conclusions are partially corresponding to the studies of Bozzolan, Favotto and Ricceri (2003), Guthrie et al. (2006) and Bruggen et al. (2009).

As the findings derived from the study suggest the level of human capital disclosure as insufficient, the achieved results might foster a debate on the importance of human capital reporting and thus improve the extent and quality of disclosing practices, especially by Polish entities. However, numerous German firms still have a potential to report better in some key areas concerning human capital.

The study has its limitations, such as a relatively small research sample and the lack of time analysis. It would be worth making a comparison between human capital disclosure today and five, ten years ago so that it would be possible to present the human capital disclosure evolution. In addition, further research shall concentrate also on more cross-country comparisons.

\section{REFERENCES}

Abeysekera, I. (2008). Intellectual capital disclosure trends: Singapore and Sri Lanka. Journal of Intellectual Capital, 9(4), 723-737.

An, Y., Harun, H., \& Sharma, U. (2014). Trends of voluntary IC disclosure in Chinese firms. Corporate Ownership \& Control, 11(3), 122-129.

April, K.A., Bosma, P., \& Deglon, D.A. (2003). IC measurement and reporting: establishing a practice in SA mining. Journal of Intellectual Capital, 4(2), 165-180.

Ariff, A.M., Cahan, S.F., \& Emanuel, D.M. (2014). Institutional environment, ownership, and disclosure of intangibles: evidence from East Asia. Journal of International Accounting Research, 13(1), 33-59.

Bismuth, A., \& Tojo, T. (2008). Creating value from intellectual assets. Journal of Intellectual Capital, 9(2), 228-245.

Bontis, N. (2003). Intellectual capital disclosure in Canadian corporations. Journal of Human Resource Costing \& Accounting, 7(1), 9-20. 
Bozzolan, S., Favotto, F., \& Ricceri, F. (2003). Italian annual intellectual capital disclosure: an empirical analysis. Journal of Intellectual Capital, 4(4), 543-558.

Brilman, J. (2002). Nowoczesne koncepcje i metody zarzqdzania. Warszawa: Polskie Wydawnictwo Ekonomiczne.

Brennan, N. (2001). Reporting intellectual capital in annual reports: evidence from Ireland. Accounting, Auditing \& Accountability Journal, 14(4), 423-436.

Bruggen, A., Vergauwen, P., \& Dao, M. (2009). Determinations of intellectual capital disclosure: evidence from Australia. Management Decision, 47(2), 233-245.

Carson, E., Ranzijn, R., Winefiel, A., \& Marsden, H. (2004). Intellectual capital: mapping employee and work group attributes. Journal of Intellectual Capital, 5(3), 443-461.

CIC (2012). Model for the measurement and management of intellectual capital: Intellectus Model. Intellectus Documents, 9/10, Madrit: Centro de Investigación de la Sociedad del Conocimiento.

Federation of European Securities Exchanges (2016). European exchange report. Retrieved on November 24, 2016 from http://www.fese.eu/images/EUROPEAN_EXCHANGE_REPORT_2015.pdf

Goh, P.C., \& Lim, K.P. (2004). Disclosing Intellectual Capital in company annual reports: evidence from Malaysia. Journal of Intellectual Capital, 5(3), 500-510.

Guthrie, J., \& Petty, R. (2000). Intellectual capital: Australian annual reporting practices. Journal of Intellectual Capital, 1(3), 241-251.

Guthrie, J., Petty, R., \& Ricceri, F. (2006). The voluntary reporting of intellectual capital comparing evidence from Hong Kong and Australia. Journal of Intellectual Capital, 7(2), 254-271.

Huang, C., Luther, R., Tayles, M., \& Haniffa, R. (2013). Human capital disclosures in developing countries: figureheads and value creators. Journal of Applied Accounting Research, 14(2), 180-196.

Joshi, M., Ubha, D.S., \& Sidhu, J. (2012). Intellectual capital disclosure by Indian and Australian information technology companies. Journal of Intellectual Capital, 13(4), 582-598.

Liao, L., Low, M., \& Davey, H. (2013). Chinese and English language version: intellectual capital disclosure. Journal of Intellectual Capital, 14(4), 661-686.

Low, M., Samkin, G., \& Li, Y. (2015). Voluntary reporting of intellectual capital: comparing the quality of disclosures from New Zealand, Australian and United Kingdom universities. Journal of Intellectual Capital, 16(4), 779-808.

Marr, B. (2003). Why do firms measure their intellectual capital?. Journal of Intellectual Capital, 4(4), 441-464.

Massingham, P., \& Tam, L. (2015). The relationship between Human capital, value creation and employee reward. Journal of Intellectual Capital, 16(2), 390-418.

Ndinguri, E., Prieto, L., \& Machtmes, K. (2012). Human capital development dynamics: the knowledge based approach. Academy of Strategic Management Journal, 11(2), 121-136.

Pablos, P.O.D. (2002). Evidence of intellectual capital measurement from Asia, Europe and the Middle East. Journal of Intellectual Capital, 3(3), 287-302.

Pablos, P.O.D. (2003). Intellectual capital reporting in Spain: a comparative view. Journal of Intellectual Capital, 4(1), 61-81.

Pulic, A. (2004). Intellectual capital - does it create or destroy value? Measuring Business Excellence, 8(1), 62-68.

Schneider, A., \& Samkin, G. (2008). Intellectual capital reporting by the New Zealand local government sector. Journal of Intellectual Capital, 9(3), 456-486.

Singh, S., \& Kansal, M. (2011). Voluntary disclosures of intellectual capital: an empirical analysis. Journal of Intellectual Capital, 12(2), 301-318. 
Sveiby, K.E. (1997). Intangible assets monitor. Journal of Human Resources Costing and Accounting, 2(1), 73-79.

Stewart, T.A. (1997). Intellectual capital. The New Wealth of Organizations. New York, NY: Doubleday.

Vishnu, S., \& Gupta, V.K. (2014). Intellectual capital and performance of pharmaceutical firms in India. Journal of Intellectual Capital, 15(1), 83-99.

Wang, Q., Sharma, U., \& Davey, H. (2016). Intellectual capital disclosure by Chinese and Indian information technology companies. Journal of Intellectual Capital, 17(3), 507-529.

Whiting, R.H., \& Woodcock, J. (2011). Firm characteristics and intellectual capital disclosure by Australian companies. Journal of Human Resource Costing \& Accounting, 15(2), 102-126.

Xiao, H. (2008). Corporate reporting of intellectual capital: evidence from China. The Business Review, 11(1), 124-129.

Yi, A., \& Davey, H. (2010). Intellectual capital disclosure in Chinese (mainland) companies. Journal of Intellectual Capital, 11(3), 326-347.

\section{Authors}

The contribution of co-authors is not equal and can be expressed as $70 \%$ of work attributed to Ł. Bryl, and $30 \%$ of work attributed to Sz. Truskolaski. Ł. Bryl prepared the literature review, methodology and conducted the study, while Sz. Truskolaski prepared the statistical calculations.

\section{tukasz Bryl}

Assistant Professor at Poznan University of Economics and Business. His research interests include intellectual capital, enterprise valuation and new economy.

Correspondence to: Łukasz Bryl, PhD, Poznan University of Economics and Business, Faculty of International Business and Economics, Al. Niepodległości 10, 61-875 Poznań, Poland, e-mail: lukasz.bryl@ue.poznan.pl

\section{Szymon Truskolaski}

Assistant Professor at Poznan University of Economics and Business. His research interests include international flows of technology, innovations and economic growth.

Correspondence to: Szymon Truskolaski, PhD, Poznan University of Economics and Business, Faculty of International Business and Economics, Al. Niepodległości 10, 61-875 Poznań, Poland, e-mail: szymon.truskolaski@ue.poznan.pl

\section{Copyright and License}

(1) (1) $\Theta$

This article is published under the terms of the Creative Commons

Attribution - NoDerivs (CC BY- ND 4.0) License

http://creativecommons.org/licenses/by-nd/4.0/

\section{Published by the Centre for Strategic and International Entrepreneurship - Krakow, Poland}

